\title{
Theoretical Investigation of Fuel Cell Producing 1000 W Power
}

\author{
Tamer Nabil*, Mohamed Mohamed Khairat Dawood \\ Mechanical Engineering Department, Suez Canal University, Ismailia, Egypt \\ Email address: \\ tamer_mtc@yahoo.com (T. Nabil),tamir.nabil@eng.suez.edu.eg (T. Nabil) \\ ${ }^{*}$ Corresponding author
}

\section{To cite this article:}

Tamer Nabil, Mohamed Mohamed Khairat Dawood. Theoretical Investigation of Fuel Cell Producing 1000 W Power. American Journal of Modern Energy. Vol. 6, No. 6, 2020, pp. 124-129. doi: 10.11648/j.ajme.20200606.13

Received: July 8, 2020; Accepted: July 23, 2020; Published: December 22, 2020

\begin{abstract}
Fuel cells offer a promising alternative to conventional fossil fuel power systems, due to their high efficiency, low environmental impact, and flexible application. Fuel cells are known for their reliability, power quality, eco-friendly nature, and fuel efficiency. Its promising power technology and extremely significant in the near future. One of the suggested power systems for residential, automotive, and portable applications is the Solid Oxide Fuel Cell (SOFC). Solid oxide fuel cell (SOFC) power devices are at the core of complex and efficient energy conversion systems for distributed power generation. Such power systems are currently in various stages of development. These power plants of the future feature complicated configurations, because of the fuel cell demands for a complex balance of plant. The purpose of this project is to review a Theoretical design of one type of fuel cell - Solid Oxide Fuel Cell (SOFC) - that can produce 1000 watt as electrical power. The type of Solid Oxide Fuel Cell (SOFC) is planar with anode supported that consists of electrolyte, cathode current collector, and anode supported. Fuel cells are attractive for several applications; however, there are several barriers that must be overcome before they can become an alternative to internal combustion engines.
\end{abstract}

Keywords: Fuel Cell, Fuel Cell Types, SOFC, Planar, Anode Supported, Theoretical Model

\section{Introduction}

A fuel cell is a device in which the energy of a fuel is converted directly into electricity direct current by an electrochemical reaction without resorting to a burning process, rather than to heat by a combustion reaction. The chemical energy of the fuel is released in the form of an electrical energy instead of heat when the fuel is oxidized in an ideal electrochemical cell. Energy conversion by a fuel cell depends largely upon catalytic electrodes, which accomplishes the electrochemical reaction to convert fuel into electric energy without involving the burning process. Efficiencies of fuel cells (40-85\%) are considerable high compared to heat engines [1].

The first fuel cell was invented in 1839 by Sir William Robert Grove. He is known as father of the fuel cells. At the London Institution, where he was Professor of Physics (1840-1847), he used his platinum zinc batteries to produce electric light for one of his lectures. The energy chemically stored in the fuels is converted into electric current by means of an electrochemical process in the fuel cell.
Fuel cells offer a promising alternative to conventional fossil fuel systems, due to their high efficiency, low environmental impact and flexible application. One of the suggested systems for residential, automotive and portable applications is the direct methanol fuel cell (DMFC), which has a proton conducting polymer membrane as electrolyte. While the fuel used most fuel cells is hydrogen (e.g. in the polymer electrolyte membrane fuel cell: PEMFC), the DMFC uses methanol as fuel. The advantage of methanol is that the existing distribution infrastructure could be used for fuel supply, unlike for hydrogen [2].

\section{Principle of Operation}

In a fuel cell, the fuel and the oxidant gases themselves comprise the anode and cathode respectively. Thus, the physical structure of a fuel cell is one where the gases are directed through flow channels to either side of the electrolyte. The electrolyte is the distinguishing feature between different types of fuel cells. Different electrolytes 
conduct different specific ions [3].

Electrolytes can be liquid or solid; some operate at high temperature, and some at low temperature. Low-temperature fuel cells tend to require a noble metal catalyst, typically platinum, to encourage the electrode reactions whereas hightemperature fuel cells do not. Most fuel cells suitable for automotive applications use a low temperature solid electrolyte that conducts hydrogenions as shown in Figure 1.

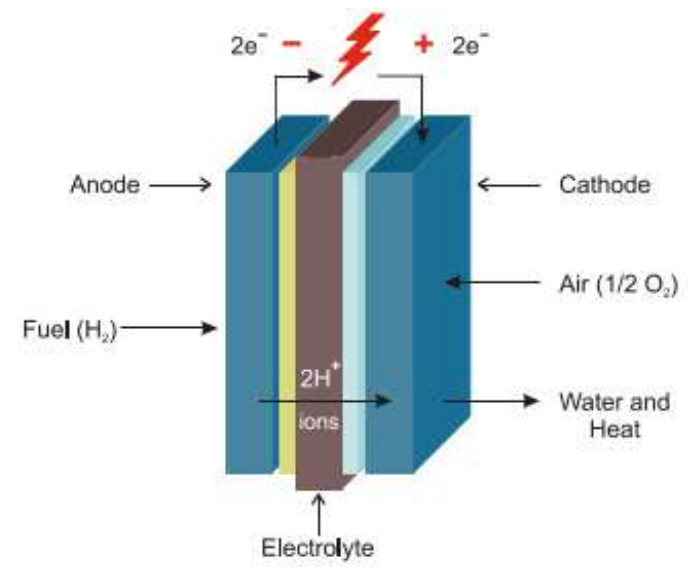

Figure 1. Generic Hydrogen Fuel Cell Operation.

In principle, a fuel cell can operate using a variety of fuels and oxidants. Hydrogen has long been recognized as the most effective fuel for practical fuel cell use since it has higher electrochemical reactivity than other fuels, such as hydrocarbons or alcohols. Even fuel cells that operate directly on fuels other than hydrogen tend to first decompose into hydrogen and other elements before the reaction takes place. Oxygen is the obvious choice of oxidant due to its high reactivity and its abundance in air.

\section{Different Types of Fuel Cells}

Fuel Cells can be classified based on their temperature of operation: high, medium and low temperature fuel cells or based on the type of electrolyte used. Primarily, the latter method of classification is used for easier understanding and practical reasons and the five common type of fuel cells are Proton exchange membrane fuel cells, (PEMFC), alkaline fuel cell (AFC), Phosphoric acid fuel cells (PAFC), Molten Carbonate fuel cells (MCFC) and Solid oxide fuel cells (SOFC). The classification determines the chemical reactions that take place, type of catalysts required operating temperature and fuel used. These factors in turn determine the most suitable applications for each type of fuel cell. The essential characteristics of the major types of fuel cells and their applications are reported [4].

Table 1. Characteristics of the main types of fuel cells.

\begin{tabular}{|c|c|c|c|c|c|c|}
\hline Type Of Fuel Cell & $\begin{array}{l}\text { Operation } \\
\text { Temperature, }{ }^{\circ} \mathrm{C}\end{array}$ & $\begin{array}{l}\text { Efficiency, } \\
\% \text { Cell }\end{array}$ & $\begin{array}{l}\text { Output, } \\
\text { Kw }\end{array}$ & Electrolyte & $\begin{array}{l}\text { Conducting } \\
\text { Ion }\end{array}$ & Fuel \\
\hline Alkali (AFC) & $60-120$ & $60-70$ & $0.3-5$ & $35-50 \% \mathrm{KOH}$ & $\mathrm{OH}^{-}$ & $\mathrm{H}_{2}$ \\
\hline Molten Carbonate (MCFC) & $620-660$ & $60-80$ & 0.10 & $\begin{array}{l}\text { Molten carbonate melts } \\
\left(\mathrm{Li}_{2} \mathrm{CO}_{3} / \mathrm{Na}_{2} \mathrm{CO}_{3}\right)\end{array}$ & $\mathrm{CO}_{3}{ }^{2-}$ & Hydrocarbons, $\mathrm{CO}$ \\
\hline Phosphoric Acid (PAFC) & $160-220$ & $40-80$ & $50-200$ & Con. $\mathrm{H}_{3} \mathrm{PO}_{4}$ & $\mathrm{H}^{+}$ & $\mathrm{H}_{2}$ \\
\hline Proton Exchange Membrane (PEMFC) & $50-80$ & $40-50$ & $50-200$ & Polymer Membrane & $\mathrm{H}^{+}$ & $\mathrm{H}_{2}, \mathrm{CH}_{3} \mathrm{OH}$ \\
\hline Solid Oxide (SOFC) & $800-1000$ & $50-60$ & $50-100$ & Yttrium-Stabilized $\mathrm{ZrO}_{2}$ & $\mathrm{O}^{2-}$ & Hydrocarbons, $\mathrm{CO}$ \\
\hline
\end{tabular}

Table 2. Comparison pf Fuel Cells.

\begin{tabular}{|c|c|c|c|c|c|c|c|}
\hline $\begin{array}{l}\text { Fuel Cell } \\
\text { Type }\end{array}$ & $\begin{array}{l}\text { Common } \\
\text { Electrolyte }\end{array}$ & $\begin{array}{l}\text { Operating } \\
\text { Temperature }\end{array}$ & $\begin{array}{l}\text { Typical Stack } \\
\text { Size }\end{array}$ & $\begin{array}{l}\text { Electrical } \\
\text { Efficiency } \\
(\text { LHV) } \\
\end{array}$ & Applications & Advantage & Challenges \\
\hline $\begin{array}{l}\text { Polymer } \\
\text { Electrolyte } \\
\text { Membrane } \\
\text { (PEM) }\end{array}$ & $\begin{array}{l}\text { Perfluoro sulfonic } \\
\text { acid }\end{array}$ & $<120^{\circ} \mathrm{C}$ & $<1 \mathrm{~kW}-100 \mathrm{~kW}$ & $\begin{array}{l}60 \% \text { direct } \\
\mathrm{H}_{2}: \mathrm{i} \\
40 \% \\
\text { reformed } \\
\text { fuel }^{\mathrm{ii}}\end{array}$ & $\begin{array}{l}\text { - backup power } \\
\text { - portable power } \\
\text { - distributed } \\
\text { generation } \\
\text { - transportation } \\
\text { - specialty vehicles }\end{array}$ & $\begin{array}{l}\text { - solid electrolyte } \\
\text { reduces corrosion \& } \\
\text { electrolyte management } \\
\text { problems } \\
\text { - low temperature } \\
\text { Quick start-up and load } \\
\text { following }\end{array}$ & $\begin{array}{l}\text { - expensive catalysts } \\
\text { - sensitive to fuel } \\
\text { impurities }\end{array}$ \\
\hline $\begin{array}{l}\text { Alkaline } \\
\text { (AFC) }\end{array}$ & $\begin{array}{l}\text { Aqueous potassium } \\
\text { hydroxide soaked in } \\
\text { a porous matrix, or } \\
\text { alkaline polymer } \\
\text { membrane }\end{array}$ & $<100^{\circ} \mathrm{C}$ & $1-100 \mathrm{~kW}$ & $60 \%$ iii & $\begin{array}{l}\text { - military } \\
\text { - space } \\
\text { - backup power } \\
\text { - transportation }\end{array}$ & $\begin{array}{l}\text { - wider range of stable } \\
\text { materials allows lower } \\
\text { cost components } \\
\text { - low temperature } \\
\text { - quick start-up }\end{array}$ & $\begin{array}{l}\text { - sensitive to } \mathrm{CO}_{2} \text { in } \\
\text { fuel and air }\end{array}$ \\
\hline $\begin{array}{l}\text { Phosphoric } \\
\text { Acid } \\
\text { (PAFC) }\end{array}$ & $\begin{array}{l}\text { Phosphoric acid } \\
\text { soaked in a porous } \\
\text { matrix or imbibed } \\
\text { in a polymer } \\
\text { membrane }\end{array}$ & $150-200^{\circ} \mathrm{C}$ & $\begin{array}{l}5-400 \mathrm{~kW}, 100 \\
\mathrm{~kW} \text { module } \\
\text { (liquid PAFC): } \\
<10 \mathrm{~kW} \text { (polymer } \\
\text { membrane) }\end{array}$ & $40 \%$ iv & $\begin{array}{l}\text { - distributed } \\
\text { generation }\end{array}$ & $\begin{array}{l}\text { - suitable for CHP } \\
\text { - Increased tolerance to } \\
\text { fuel impurities }\end{array}$ & $\begin{array}{l}\text { - expensive catalysts } \\
\text { - long start-up time } \\
\text { - sulfur sensitivity }\end{array}$ \\
\hline $\begin{array}{l}\text { Molten } \\
\text { Carbonate } \\
(\mathrm{MCFC})\end{array}$ & $\begin{array}{l}\text { Molten lithium, } \\
\text { sodium, and/or } \\
\text { potassium } \\
\text { carbonates, soaked } \\
\text { in a porous matrix }\end{array}$ & $600-700^{\circ} \mathrm{C}$ & $\begin{array}{l}300 \mathrm{~kW}-3 \mathrm{MW} \\
300 \mathrm{~kW} \text { module }\end{array}$ & $50 \% \mathrm{v}$ & $\begin{array}{l}\text { - electric utility } \\
\text { - distributed } \\
\text { generation }\end{array}$ & $\begin{array}{l}\text { - high efficiency } \\
\text { - fuel flexibility } \\
\text { - suitable for CHP } \\
\text { - hybrid/gas turbine } \\
\text { cycle }\end{array}$ & $\begin{array}{l}\text { - high temperature } \\
\text { corrosion and } \\
\text { breakdown of cell } \\
\text { component } \\
\text { - long start-up time }\end{array}$ \\
\hline
\end{tabular}




\begin{tabular}{|c|c|c|c|c|c|c|c|}
\hline $\begin{array}{l}\text { Fuel Cell } \\
\text { Type }\end{array}$ & $\begin{array}{l}\text { Common } \\
\text { Electrolyte }\end{array}$ & $\begin{array}{l}\text { Operating } \\
\text { Temperature }\end{array}$ & $\begin{array}{l}\text { Typical Stack } \\
\text { Size }\end{array}$ & $\begin{array}{l}\text { Electrical } \\
\text { Efficiency } \\
\text { (LHV) }\end{array}$ & Applications & Advantage & Challenges \\
\hline $\begin{array}{l}\text { Solid Oxide } \\
\text { (SOFC) }\end{array}$ & $\begin{array}{l}\text { Yttria stabilized } \\
\text { zirconia }\end{array}$ & $500-1000^{\circ} \mathrm{C}$ & $1 \mathrm{~kW}-2 \mathrm{~kW}$ & $60 \% \mathrm{vi}$ & $\begin{array}{l}\text { - Auxiliary power } \\
\text { - electric utility } \\
\text { - distributed } \\
\text { generation }\end{array}$ & $\begin{array}{l}\text { - high efficiency } \\
\text { - fuel flexibility } \\
\text { - solid electrolyte } \\
\text { - suitable for CHP } \\
\text { - hybrid/gas turbine } \\
\text { cycle }\end{array}$ & $\begin{array}{l}\text { - low power density } \\
\text { - high temperature } \\
\text { corrosion and } \\
\text { breakdown of cell } \\
\text { component } \\
\text { - long start-up time } \\
\text { - limited number of } \\
\text { shutdowns }\end{array}$ \\
\hline
\end{tabular}

\section{Solid Oxide Fuel Cells (SOFC)}

SOFC is a solid electrochemical conversion device that directly converts the chemical energy of fuel into electricity. In this device, fuel is oxidized with the assistance of oxygen; the air is employed as the root of oxygen. The advantage of this cell is that it doesn't contain a liquid electrolyte, so there's no probability of liquid flooding. The first structure of the unit consists of an anode, cathode, and electrolyte; interconnect is critical for assembling many cells together and sealant is another optional component for planner sort of SOFC to layover mixing of fuel and air [5].

The electrolyte is nonporous to maintain a strategic distance from commixture of fuel and air directly while the electrodes are porous to permit fuel and air to return in touch with triple-phase boundary (TPB) where the reaction takes place between fuel gas and oxidant in presence of electrode and electrolyte; electrolyte must be ion-conducting alongside electronically non-conducting while the electrodes must be both ionic and electronically conductive to facilitate current collection (in cathode) and catalytic body process.

Solid oxide fuel cells use an electrolyte that conducts oxide $\left(\mathrm{O}_{2}\right)$ ions from the cathode to the anode. This is the opposite of most types of fuel cells, which conduct hydrogen ions from the anode to the cathode. The electrolyte is composed of a solid oxide, usually zirconia (stabilized with other rare earth element oxides like yttrium), and takes the form of a ceramic [6].

Solid oxide fuel cells are built like computer chips through sequential deposition of various layers of material. Common configurations include tubular and flat (planar) designs. The designs differ in the extent of dissipative losses within cells, in the manner of sealing between the fuel and oxidant channels, and in the manner that cell-to-cell electrical connections are made in a stack of cells. Metals such as nickel and cobalt can be used as electrode materials. Solid oxide fuel cells operate at about $1830^{\circ} \mathrm{F}\left(1000^{\circ} \mathrm{C}\right)$ and a pressure of 15 psig (1 bar). Each cell can produce between 0.8 and 1.0 VDC.

\section{SOLID OXIDE FUEL CELL: HOW IT WORKS}

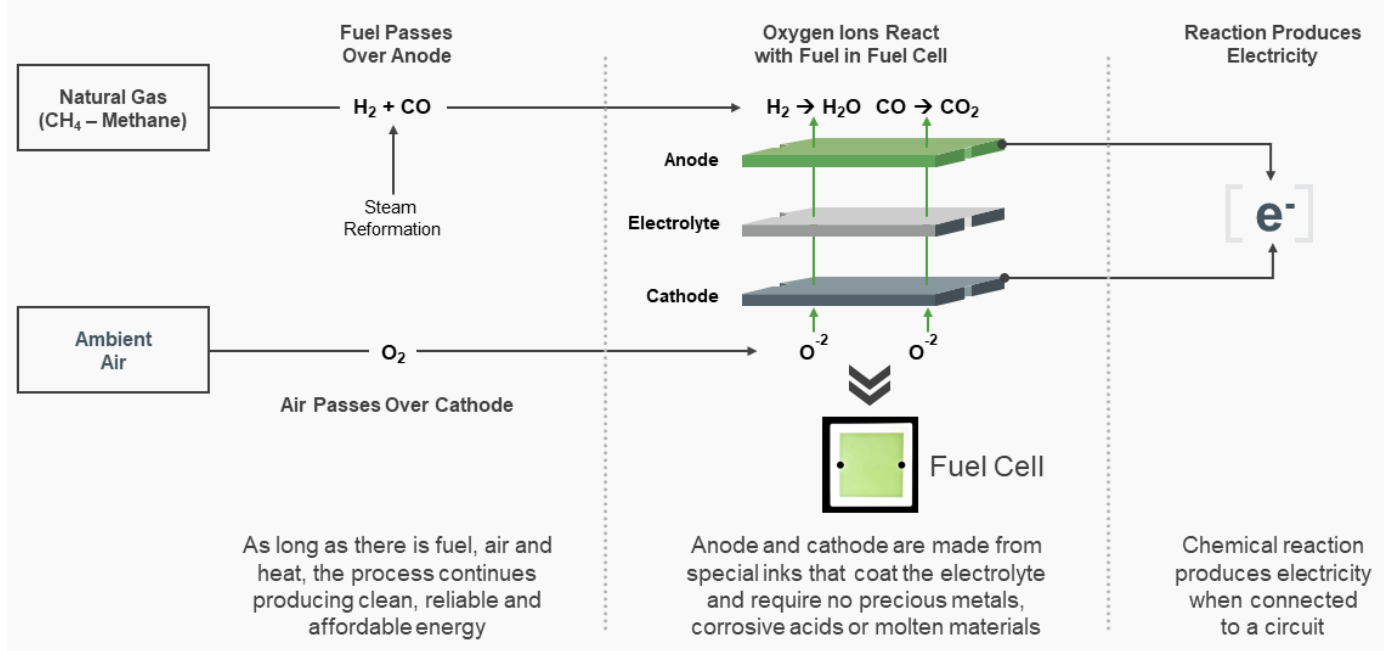

Figure 2. Solid Oxide Fuel Cell.

There are several types of SOFC based on the cell support, SOFC is divided into three types: electrolyte, cathode and anode-supported.

1. Electrolyte supported cell:

Electrolyte must be thick enough to hold the load of the whole cell. On the other hand, thick electrolyte provides huge amount of ohmic resistance which reduces cell performance.
Therefore, researchers are more interested in electrode supported cell [7].

2. Cathode-supported cell:

Cathode-supported cell is not also finding potential application because of its poor support. Oxygen is passed through cathode; volume of oxygen molecule is higher than that of hydrogen. Therefore, larger pores are required in cathode than 
in anode. Large pore is not desirable for the component which is intended to provide mechanical strength to the cell. Therefore, cathode supported cell is almost abandoned [8].

3. Anode-supported cell:

Anode-supported SOFCs are widely used. Hydrogen molecule passes through anode; since its molecular size is too small it can easily pass through very small pores. Therefore, anode with small pores can provide good mechanical strength to the cell [9].

Advantages and Disadvantages of SOFC [10]:

The advantages of solid oxide fuel cells are that they:

1. Support spontaneous internal reforming of hydrocarbon fuels. Since oxide ions - rather than hydrogen ions travel through the electrolyte, the fuel cells can in principle be used to oxidize any gaseous fuel.

2. Operate equally well using wet or dry fuels

3. Generate high-grade waste heat

4. Have fast reaction kinetics

5. Have very high efficiency

6. Can operate at higher current densities than molten carbonate fuel cells

7. Have a solid electrolyte, avoiding problems associated with handling liquids

8. Can be fabricated in a variety of self-supporting shapes and configurations

9. Do not need noble metal catalysts

The disadvantages are that they [11]:

1. Require the development of suitable materials that have the required conductivity, remain solid at high temperatures, are chemically compatible with other cell components, are dimensionally stable, have high endurance and lend themselves to fabrication.

2. Do not yet have practical fabrication processes

3 . The technology is not yet mature

\section{Reaction}

Fuel cells are electro-chemical devices which are used to convert the chemical energy of a gaseous fuel directly into electricity. In fuel cells, a chemical reaction takes place to convert hydrogen and oxygen into water, releasing electrons in the process. In other words, that hydrogen fuel is burnt in a simple reaction to produce electric current and water. A fuel cell consists of two electrodes, known as anode and cathode that are separated by an electrolyte is shown in Figure 3 [12].

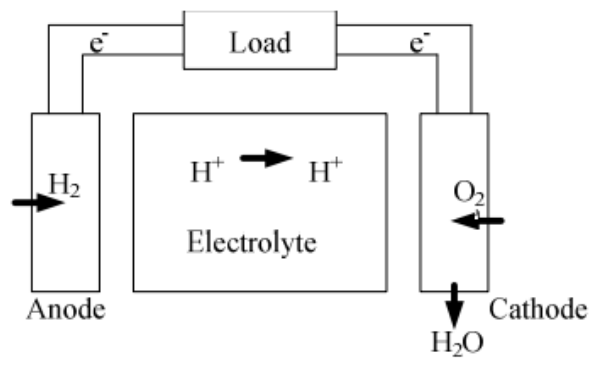

Figure 3. Schematic diagram of a fuel cell.
Oxygen is passed over the cathode and hydrogen over the anode. Hydrogen ions are formed together with electrons at the anode [13]. Hydrogen ions migrate to the cathode through the electrolyte and electrons produced at the anode flow through an external circuit to the cathode [14]. At the cathode, they are combining with oxygen to form water. The flow of electrons through the external circuit provides the current cell. In order to storage energy, Hydrogen and Oxygen are obtained from water by passing a direct current in a process known as electrolysis [15]. The chemical reactions that take place inside the SOFC and directly involved in the production of electricity are as follows [16].

At anode (fuel electrode)

$$
2 \mathrm{H}_{2}+2 \mathrm{O}^{2-} \rightarrow 2 \mathrm{H}_{2} \mathrm{O}+4 e^{-}
$$

And

$$
2 \mathrm{CO}+2 \mathrm{O}^{2-} \rightarrow 2 \mathrm{CO}_{2}+4 e^{-}
$$

At cathode (air electrode)

$$
\mathrm{O}_{2}+4 e^{-} \rightarrow 2 e^{2-}
$$

Overall cell reaction can be expressed as

$$
\mathrm{H}_{2}+\frac{1}{2} \mathrm{O}_{2} \rightarrow \mathrm{H}_{2} \mathrm{O}
$$

\subsection{Solid Oxide Fuel Cell Mathematical Model}

A simulation model is developed for the SOFC. Considering Ohmic losses of the stack, the expression of total stack voltage can be written as [17]:

$$
V_{f c}=N_{0}\left(E_{0}+\frac{R T}{2 F}\left(\ln \frac{P_{\mathrm{H}_{2} P_{O_{2}}}{ }^{0.5}}{P_{\mathrm{H}_{2} \mathrm{O}}}\right)\right)-r I_{f c}
$$

Where $\mathrm{V}$ is the total stack voltage and $\mathrm{rI}$ is ohmic loss of the stack.

The output voltage of the stack is given by the Nernst equation [18]. The ohmic loss of the stack is because of the resistance of the electrodes and to the resistance of the flow of oxygen ions through the electrolyte. Partial pressure of hydrogen, oxygen and water are given in following equations [19]:

$$
\begin{aligned}
& P_{\mathrm{H}_{2}}=\left(\frac{\frac{1}{\mathrm{KH}_{2}}}{1+\tau_{\mathrm{H}_{2}} S}\right)\left(q H_{2}-2 K_{r} I\right) \\
& P_{\mathrm{O}_{2}}=\left(\frac{\frac{1}{\mathrm{KO}_{2}}}{1+\tau_{O_{2}} S}\right)\left(q O_{2}-2 K_{r} I\right) \\
& P_{\mathrm{H}_{2} \mathrm{O}}=\left(\frac{\frac{1}{\mathrm{KH}_{2} \mathrm{O}}}{1+\tau_{\mathrm{H}_{2} \mathrm{O}} S}\right)\left(2 K_{r} I\right)
\end{aligned}
$$

The slow dynamics of the fuel cell current is represented by following equation:

$$
I=\left(\frac{I_{\text {ref }}}{1+\tau_{e} S}\right)
$$


$\mathrm{I}_{\mathrm{ref}}$ is the reference current which is given by following equation:

$$
I_{\text {ref }}=\left(\frac{P_{r e f}}{V_{f c}}\right)
$$

Fuel and oxygen flow are given by following equation:

$$
\begin{aligned}
& q H_{2}^{r}=2 K_{r} I \\
& q O_{2}^{r}=\frac{q H_{2}}{r H O}
\end{aligned}
$$

The power output of the fuel cell system is the product of stack current and voltage. The block diagram represents SOFC dynamic model is shown in the Figure 4 [20].

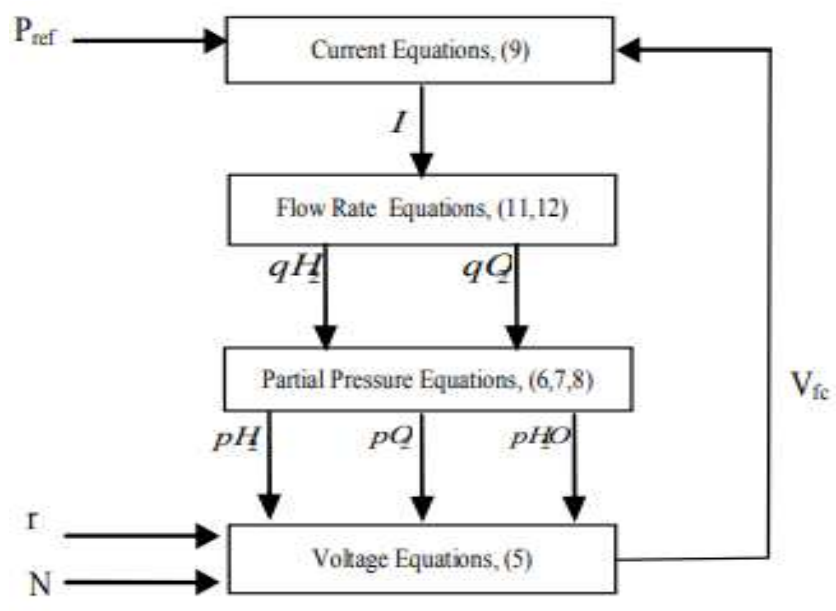

Figure 4. Block diagram for dynamic model of SOFC.

\subsection{Solid Oxide Fuel Cell (SOFC) 1KW Design Parameters}

\begin{tabular}{ll}
\hline Representation & Value \\
\hline Cell design & Planar, Anode supported \\
Anode Material & Ni-8YSZ, $250 \mu \mathrm{m}$ thick \\
Electrolyte Material & $8 \mathrm{YSZ}, 8 \mu \mathrm{m}$ thick \\
Cathode Material & $\mathrm{LSCF}, 30 \mu \mathrm{m}$ thick \\
Operating temperature $(\mathrm{T})$ & $1273 \mathrm{~K}$ \\
Faraday's constant $(\mathrm{F})$ & $96487 \mathrm{C} / \mathrm{mol}$ \\
Universal gas constant $(\mathrm{R})$ & $8314 \mathrm{~J} /(\mathrm{kmol} \mathrm{K})$ \\
Standard reversible cell potential $(\mathrm{E})$ & $0.8 \mathrm{~V}$ \\
Cell Current Density & $0.4 \mathrm{~A} / \mathrm{cm}^{2}$ \\
Cell Power Density & $0.32 \mathrm{~A} / \mathrm{cm}^{2}$ \\
Active Area Per Cell & $200 \mathrm{~cm}{ }^{2}$ \\
Power per cell & $64 \mathrm{~W}$ \\
Efficiency & $50-60 \%$ \\
Number of cells $(\mathrm{N})$ & 32 \\
Constant $(\mathrm{K}=\mathrm{N} / 4 \mathrm{~F})$ & $0.996 \times 10-6 \mathrm{kmol} /(\mathrm{s} \mathrm{A})$ \\
Valve molar constant for hydrogen $\left(\mathrm{KH}_{2}\right)$ & $8.43 \times 10-4 \mathrm{kmol} /(\mathrm{s} \mathrm{atm})$ \\
Valve molar constant for oxygen $\left(\mathrm{KO}_{2}\right)$ & $2.81 \times 10-4 \mathrm{kmol} /(\mathrm{s} \mathrm{atm})$ \\
Valve molar constant for water $\left(\mathrm{KH}_{2} \mathrm{O}\right)$ & $2.52 \times 10-3 \mathrm{kmol} /(\mathrm{s} \mathrm{atm})$ \\
Response time for hydrogen flow $\left(\mathrm{T}_{\mathrm{H} 2}\right)$ & $26.1 \mathrm{~s}$ \\
Response time for water flow $\left(\mathrm{T}_{\mathrm{H} 2 \mathrm{O}}\right)$ & $78.3 \mathrm{~s}$ \\
Response time for oxygen flow $\left(\mathrm{T}_{\mathrm{O} 2}\right)$ & $2.91 \mathrm{~s}$ \\
Ohmic loss (r) & $0.126 \Omega$ \\
Electrical response time $\left(\mathrm{T}_{\mathrm{e}}\right)$ & $0.8 \mathrm{~s}$ \\
Fuel processor response time $\left(\mathrm{T}_{\mathrm{f}}\right)$ & $5 \mathrm{~s}$ \\
Ratio of hydrogen to oxygen $\left(\mathrm{r}_{\mathrm{HO}}\right)$ & 1.145 \\
\hline
\end{tabular}

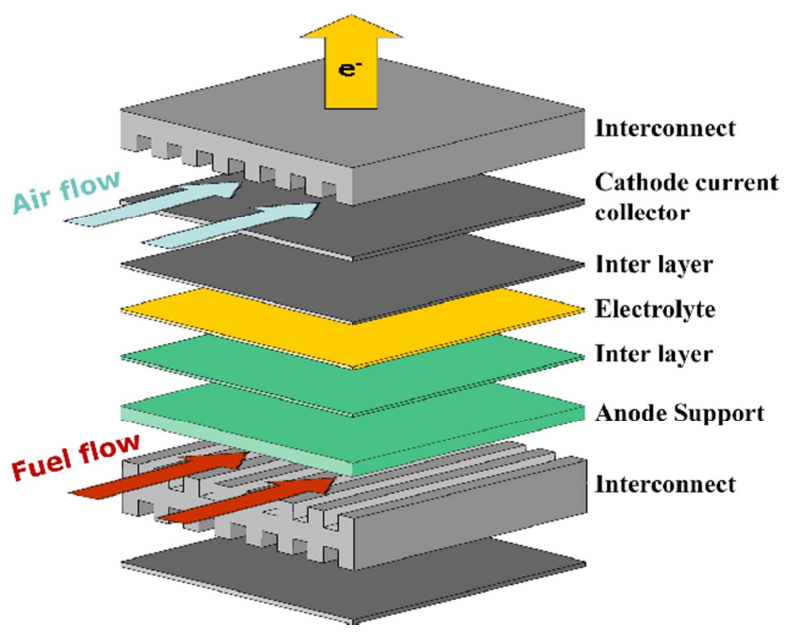

Figure 5. SOFC Planar and Anode supported design.

\section{Conclusion}

To conclude this study, the Solid Oxide Fuel Cell (SOFC) of today's industry have not yet reached its fully potential. With new technologies and innovations more and more SOFC features are implemented in the industry. In recent years the SOFC features are getting more popular as a result of efficient product in industry. This opens up for new types of SOFC features in order to find new ways to the power production [21].

In this study, different SOFC features have been emphasized. It's found that the most important thing is the design the cell and the type of support. As we saw in the previous sections, the models that have Electrolyte and Cathode supported cell are not efficient as the models have Anode-supported.

Finally, the performance of Solid Oxide Fuel Cell (SOFC) is depending on the number of cells and the type of cell's supporters.

\section{Future Work}

Many different adaptations, tests, and experiments have been left for the future due to lack of time (i.e. the experiments with real data are usually very time consuming, requiring even days to finish a single run). Future work concerns deeper analysis of particular mechanisms, new proposals to try different methods, or simply curiosity.

\section{References}

[1] Baldi, F., Moret, S., Tammi, K., and Maréchal F. "The role of solid oxide fuel cells in future ship energy system" Energy, 194, 2020.

[2] Zhu, B., Raza, R., Fan, L., and Sun C. "Solid Oxide Fuel Cells" Energy, 2020.

[3] Tsukuda, H., Koga, S., and Matake N. "Material for solid oxide fuel cell interconnector, unit cell for solid oxide fuel cell, and solid oxide fuel cell" 2014. 
[4] Atkinson, A., Skinner, S., and Kilner J. "Solid Oxide Fuel Cells solid oxide fuel cell (SOFC)" 10.1007/978-1-44190851-3 139.2012.

[5] Ohmori, M., Shimogawa, N., Okada S., and Nanataki, T. "Sheet body of solid oxide fuel cell, and solid oxide fuel cell" 2013.

[6] Shin, T., Choi, J., and Lim H. "Solid Oxide Fuel Cell Materials" 10.1007/978-3-319-59906-9_6.2018.

[7] Sun, C. "Anodes for Solid Oxide Fuel Cell" 10.1002/9783527812790.ch4.2020.

[8] He, T., Zhou, Q., and Jin F. "Cathodes for Solid Oxide Fuel Cell” 10.1002/9783527812790.ch3.2020.

[9] Khandale, A., and Bhoga S. "Electrocatalysts in Solid Oxide Fuel Cells" 10.1201/9780429296871-7.2020.

[10] San, J. "Development of lanthanum strontium manganite perovskite cathode materials of solid oxide fuel cells: a review" 10.1007/s10853-008-2966-6,2008.

[11] Andersson, M., and Sunden B. "Technology review - solid oxide fuel cell” 2015.

[12] Patil, M., Bhagat, S., Sapkal, R., and Sapkal V. "A Review on the Fuel Cells Development" Sci. Rev. Chem. Commun. 1. 2011.

[13] Biswas M. "Electrolyte Materials for Solid Oxide Fuel Cell" Journal of Powder Metallurgy and Mining. 02. 10.4172/21689806.1000e114.2013.
[14] Nesaraj A. "Recent developments in solid oxide fuel cell technology - A review" Journal of Scientific and Industrial Research. 69. 2010.

[15] Singh, A., and Baredar P. "Solid Oxide Fuel Cells" 10.1201/9780429353192-11.2020.

[16] Nagata, S., Kasuga, Y., Hayashi, K., kaga, Y., ohno, Y., and Fukuda R." "Development of solid oxide fuel cell" 1988.

[17] Fergus J. "Electrolyte for Solid Oxide Fuel Cells" Journal of Power $\quad$ Sources. $162 . \quad 30-40$. 10.1016/j.jpowsour.2006.06.062.2006.

[18] Crawley, G., Munroe N. "Solid oxide fuel cells (SOFC)" Fuel Cell Today. 1-16. 2007.

[19] Wenxia, L., Hasinska, K., Seabaugh, M., Swartz, S., and Lannutti J. "Curvature in Solid Oxide Fuel Cells" Journal of Power Sources. $138.145-155$ 10.1016/j.jpowsour.2004.06.034.2004.

[20] Salam, A., Hannan, M., Mohamed A. "Dynamic Modeling and Simulation of Solid Oxide Fuel Cell System" 813 - 818. 10.1109/PECON.2008.4762585.2009.

[21] Gelen, A., Yalcinoz T. "The performance of thermal based modified solid oxide fuel cell (SOFC) model under different DC load conditions" Journal of Engineering Research. 3. 5975. 10.7603/s40632-015-0023-6.2015. 